\title{
Polysèmes
}

Revue d'études intertextuelles et intermédiales

\section{Echoing as Self-Fashioning in the Essay: Hazlitt's Quoting and Misquoting of Shakespeare}

L'écho comme trait stylitique de l'essai : les citations de Shakespeare dans

l'œuvre de Hazlitt

\section{Mario Aquilina}

\section{OpenEdition}

Journals

Electronic version

URL: http://journals.openedition.org/polysemes/4262

DOI: 10.4000/polysemes.4262

ISSN: 2496-4212

Publisher

SAIT

Electronic reference

Mario Aquilina, «Echoing as Self-Fashioning in the Essay: Hazlitt's Quoting and Misquoting of

Shakespeare ", Polysèmes [Online], 20 | 2018, Online since 15 December 2018, connection on 23 April 2019. URL : http://journals.openedition.org/polysemes/4262 ; DOI : 10.4000/polysemes.4262

This text was automatically generated on 23 April 2019.

Polysèmes 


\section{Echoing as Self-Fashioning in the Essay: Hazlitt's Quoting and Misquoting of Shakespeare}

L'écho comme trait stylitique de l'essai : les citations de Shakespeare dans

l'œuvre de Hazlitt

Mario Aquilina

\section{Between egoism and a shared literary culture}

1 The personal essay form has traditionally been shaped by two formidable forces, pulling in what may seem like diametrically opposed directions. On the one hand, there is the centrality of the self of the essayist or what Virginia Woolf describes as the tendency of the essayist to veer towards "egoism":

[I]f you say that an essay is essentially egoistical you will not exclude many essays and you will certainly include a portentous number. Almost all essays begin with a capital I-"I think", "I feel"-and when you have said that, it is clear that you are not writing history or philosophy or biography or anything but an essay, which may be brilliant or profound, which may deal with the immortality of the soul, or the rheumatism in your left shoulder, but is primarily an expression of personal opinion. (Woolf 4)

The term, "egoistical", as used here by Woolf, should not be conflated with "egotistic" and its negative connotations. To make a subtle distinction of meaning that may easily be missed, while egotism names the quality of being excessively conceited or absorbed in oneself, "egoism", which is often used interchangeably with "egotism", is also a philosophical term for the theory that one's self is-or should be-the fountain from which motivation springs. It is in this sense that Woolf writes that the essay is primarily an "egoistical" form, that is, a form which is primarily "an expression of personal opionion". 
2 However, it is also a common characteristic of the personal essay that the essayist tends to be open to, and sometimes dependent on, a "shared literary culture" (Lopate 131), or what William H. Gass calls "the community of writers" (Gass 109) and essayists who have come before. The essayist shows this openness by quoting freely and frequently. Montaigne (1533-92), widely considered the father of the modern essay, already embodies these opposite forces as he quotes extensively, especially from classical sources, while, at the same time, writing about very personal issues in such a way that, as he puts it, his "kinsfolk and friends [may] therein recover some traits of [his] conditions and humors, and by that means preserve more whole, and more life-like, the knowledge they had of [him]" (Montaigne v).

3 What follows explores these contrary dynamics: the centripetal force that pulls the world towards the personality of the essayist and the centrifugal veering of the essayist towards a shared community of writing through the echoing of others. It does this by looking at William Hazlitt (1778-1830) and, more specifically, at Hazlitt's echoing of Shakespeare in his personal essays. Hazlitt uses Shakespeare's words repeatedly: Jonathan Bate counts more than 2400 quotations from Shakespeare in P.P. Howe's edition of Hazlitt's complete works (Bate 1984, 26), remarking that "Hazlitt felt it was perfectly natural and unexceptionable to use Shakespeare's words" (Bate 1984, 29). However, it is also significant that Hazlitt does not simply echo Shakespeare repeatedly, but he often mis quotes him. The nature and function of these misquotations are key considerations in this essay, in which it is claimed that Hazlitt's misquotations of Shakespeare are not simply errors but a signature element of an essayistic style marked by an echoing that recalls the well-known original-thus appealing to the force of that which is already known by his readers-while veering from it, over and over again, into new directions as a form of selffashioning.

\section{A tessellation of borrowed fragments}

In "A Letter to William Gifford, Esq.", William Hazlitt responds in detail to what Leigh Hunt describes as the "wretched cavilings, wilful falsehoods and omissions, and servile malignity of [Gifford's] well-known articles in the Quarterly Review" about Hazlitt's writing (Hunt n.p.). In 87 pages, Hazlitt takes to task his staunchest critic's comments about his work not only by pointing out Gifford's selling out to power, or as Hazlitt puts it, his being "by appointment, literary toad-eater to greatness, and taster to the Court" (Hazlitt 1819, 41), but also by responding in detail, sometimes line by line and word by word, to Gifford's many objections to his writing, among which is Hazlitt's quoting and misquoting of Shakespeare. ${ }^{1}$

5 Hazlitt, of course, is a well-known Shakespearean critic, and his Characters of Shakespeare's Plays (1817) as well as numerous theatre reviews written for The Morning Chronicle, Examiner, and The Champion, contributed significantly to the canonization of Shakespeare in the early nineteenth century. However, while as John Kinnaird points out, "after 1820 Hazlitt never returns (except, incidentally in one essay ["Sir Walter Scott, Racine, and Shakespear [sic]" (1826)]) to Shakespearean criticism", Hazlitt continues to extensively quote Shakespeare (and often misquote him) as long as he continues to write (Kinnaird 175). 
Gifford's attack on Hazlitt's reliance on Shakespeare is at least two pronged. In a 1818 review of Hazlitt's Lectures on the English Poets, he accuses Hazlitt of overdoing the echoing of Shakespeare, and he also points out inaccuracies in these quotations: "Next to want of precision, the most striking peculiarity of his style is the odd expression with which it is diversified, from popular poets, especially from Shakespeare" (Gifford 1818, 426). About the overreliance, Gifford writes: "If a trifling thing is to be told, [Hazlitt] will not mention it in common language: he must give it, if possible, in words which the Bard of Avon has somewhere used". This "constant stitching in of these patches", Gifford argues, leads to "deformity" in Hazlitt's style (Gifford 1818, 426).

While Shakespeare is by a long stretch the one whom Hazlitt quotes most frequently, he is only one of the many sources Hazlitt uses in his essays, with Milton, Wordsworth, Dryden and Pope being some of his other favourites. There are numerous passages in Hazlitt's essays, like the following one, that could be described, using Tom Paulin's words, as a "bricolage of quotations" (Paulin 27).

Those who are ready to fancy themselves Raphaels and Homers are very inferior men indeed-they have not even an idea of the mighty names that "they take in vain". They are as deficient in pride as in modesty, and have not so much as served an apprenticeship to a true and honourable ambition. They mistake a momentary popularity for lasting renown, and a sanguine temperament for the inspiration of genius. The love of fame is too high and delicate a feeling in the mind to be mixed up with realities-it is a solitary abstraction, the secret sigh of the soul-

"It is all one as we should love

A bright particular star, and think to wed it."

A name "fast-anchored in the deep abyss of time" is like a star twinkling in the firmament, cold, silent, distant, but eternal and sublime; and our transmitting one to posterity is as if we should contemplate our translation to the skies. (Hazlitt 1928 [1826], 124-125)

In this extract, Hazlitt echoes, in quick succession, the Book of Exodus, Shakespeare's All's Well that Ends Well, and William Cowper's "Retirement" to make his point, and, in so doing adapts (or misquotes) each of the three sources he borrows from, none of which is cited directly in Hazlitt's text.

8 Thomas De Quincey, like Gifford, identifies Hazlitt's reliance on quotation as one "vice of Mr. Hazlitt's composition", and, using pejoratively words that post-structuralist theorists of intertextuality would use descriptively, censures him for reducing his essays to "a series of mosaics, a tessellation made up from borrowed fragments" (De Quincey 1873 [1838], 134-135).

De Quincey's main complaint about Hazlitt's derivative style is that he feels it is “dishonest" (De Quincey 136) “to express one's own thoughts by another man's words" (De Quincey 135). If the thought to be expressed is not powerful enough, De Quincey argues, then it should not be camouflaged by quoting others. If, on the other hand, the thought is compelling, De Quincey asks, "how can it bend to another man's expression of it?" (De Quincey 135). De Quincey labels Hazlitt's work “a continued cento of splendid passages from other people" (De Quincey 136) designed to give the impression of authorial eloquence but really being little more than a hoarding of robbed phrases through a "few passages of transition or brief clauses of connexion [sic]" (De Quincey 136). The reference to masculinity ("another man's words") as well as the phrases connoting weakness and passivity ("bend to another man's expression") reiterate the association between style and man or style and masculine virility that has classical roots and that Jacques Derrida sees as dominating a phallocentric conception of writing. 
In such contexts, style-especially ornateness when seen as obfuscating "truth"-is often associated with female delicacy and dissimulation, ${ }^{2}$ but as Derrida demonstrates in Spurs: Nietzsche's Styles (1979), style also connotes male potency in formulations that are not free of sexual nuances and that bring together gestures of inscription, pointing and perforation. De Quincey seems to suggest that echoing-or "bend[ing] to another man's expression"-shows both a lack of authorial sovereignty over language as well as dishonesty, and, in so doing, indirectly castigates Hazlitt for embodying a feminine conception of writing in the style of Echo.

De Quincey's objections assume that there is an indissoluble nexus between powerful thought and its expression, substance and form, and that this link is crucial to constructing a strong sense of (a masculine) individual style. For him, Hazlitt's reliance on "alien organs" not only betrays laxity of thinking or carelessness in expression but also fails to show the "impress of one's own individuality" on language (De Quincey 1873, 135. Note the language of pointing and pressing Derrida highlights in Spurs: Nietzsche's Styles [1979]). The conception of the authorial voice and of the work that De Quincey applies here prioritises ideas of wholeness, originality and organicism that are questioned, for instance, in twentieth-century theories of textuality.

De Quincey's description of Hazlitt's work as a "series of mosaics" and as resembling the genre of the cento (De Quincey 1873, 135)-which Samuel Johnson, also pejoratively, describes as a "composition formed by joining scraps from other authors" (OED)-is meant as a negative critique. At stake is the organicism as well as the masculinity of individual style that seem to be disrupted and unraveled by the infiltration of "alien" voices and the abdication of the authority of thought to a constellation of others (de Quincey 1873, 135). However, very similar terminology is used by Julia Kristeva and Roland Barthes, for instance, to describe (rather than evaluate) the very nature of textuality. Kristeva writes that any text "is constructed of a mosaic of quotations; any text is the absorption and transformation of another" (Kristeva 1986, 37). For Barthes, "any text is a new tissue of past quotations" (Barthes 1981, 39). As Philip Hardie points out in a discussion of "Mosaics and Intertextuality", there is a fine difference between the use of the mosaic image and the notion of intertextuality. Mosaics are made by the placing next to each other of hard little fragments, while "intertextuality" is a term that suggests "interweaving or intertwining threads of different colours so that they lose their separate, atomistic identities and work together in a larger pattern" (Hardie, forthcoming, n.p.). As Hardie argues, the distinction is problematic because a mosaic is perceived as "more than the sum of its tessellated parts" and "gives the impression that it is all of one piece" (Hardie, forthcoming, n.p.). And indeed, even Barthes's and Kristeva's conception of intertextuality seems to hold on to the idea of a text that does not simply incorporate fragments but also somehow transforms them. Kristeva speaks of "transformation", and Barthes of the "new". While the renovation of material is not necessarily attributed to an authorial hand, neither of them understands the textinherently intertextual-as simply a stitching together of atomistic fragments.

De Quincey, however, criticizes Hazlitt's style precisely for being unable to transform the material he borrows from others. All Hazlitt does, De Quincey implies, is to simply stitch phrases together through "clauses of connection". To rephrase this, style is the man, but what man is this when his style is a derivative hodgepodge of the words of others? We will return to the relation between style and the echoing of others below, but before that, let us look at the second major objection raised by Gifford and others to Hazlitt's quoting 
of Shakespeare: apart from overusing Shakespeare, Hazlitt often misuses him by mis quoting him. Gifford calls Hazlitt out on one particular "omission of a line in a quotation from a well-known passage [sic.]" from Shakespeare, but Hazlitt's writing could have presented quite a few other instances of misquotation for Gifford to criticize (Hazlitt 1819, 55).

In his letter, Hazlitt responds to both of Gifford's claims. As to the charge of including Shakespeare too often, he states: "I can only answer, that 'I would not change that vice for your best virtue"' (Hazlitt 1819, 59). Hazlitt believes that Gifford cannot understand his use of Shakespeare because Gifford "know[s] nothing of Shakespear [sic], nor of what is thought about him" (Hazlitt 1819, 55-56). He lacks sympathy not only for Shakespeare's writing, but also for his characters and, unlike him, Gifford is unable to make Shakespeare "ever 'present to [his] mind's eye" (Hazlitt 1819, 56) or, to use Jonathan Bate's terms, to tolerate this sympathetic identification in others (Bate 1984). Quoting Shakespeare is for Hazlitt a consequence, in his writing style, of his identification with Shakespeare and his characters, and this is a conception of the self or the writing self as open to the other that is essential in understanding Hazlitt's use of Shakespearean words and phrases in his writing.

About the specific misquotation highlighted by Gifford, Hazlitt is somewhat more evasive. He insists that Gifford's claim that he did it to "improve the metre" of Shakespeare's verse, is "ridiculous", but he does not provide any justification or explanation for it (Hazlitt 1819, 55).

The animosity felt by Gifford, a political enemy who regularly savaged Hazlitt in the government-aligned Quarterly Review, explains some of the faultfinding in Gifford's critique of Hazlitt. As Hazlitt himself points out, Gifford's strategy is to taint Hazlitt's reputation as a Shakespearean critic so that he can then undermine the validity of his political views and arguments:

If any doubts could ever have been entertained on the subject of your motives and views, you have taken care to remove them. Thus you conclude your account of the characters of Shakespear's plays with saying, that you should not have condescended to notice the senseless and wicked sophistry of the work at all, but that "you conceived it might not be unprofitable to shew how small a portion of talent and literature is necessary to carry on the trade of sedition". I should think it requires as much talent and literature to carry on my trade as yours. This acknowledgment of yours is "remarkable for its truth and naiveté". It is a pledge from your own mouth of your impartiality and candour. With this object in view, "you have selected a few specimens of my ethics and criticism", (they are very few, and of course you would select no others), just sufficient, (with your garbling and additions), to prove "that my knowledge of Shakespear and the English language is exactly on a par with the purity of my morals, and the depth of my understanding". (Hazlitt 1819, 39) ${ }^{3}$

Gifford, then, has ulterior motives for criticizing Hazlitt's echoing of Shakespeare, but he is factually correct when he points out the extraordinary frequency with which Hazlitt quotes Shakespeare as well as the fact that Hazlitt sometimes misquotes Shakespeare. Indeed, as Tom Paulin and David Chandler put it, Hazlitt "quoted compulsively" and he "freely adapted the material he was quoting", rarely citing it directly (Hazlitt 2000, 553).

De Quincey too may have had political and personal motives for criticising Hazlitt. A staunch, if somewhat heterodox, conservative, De Quincey was also involved in a personal controversy with Hazlitt about him having supposedly borrowed (or echoed), without citing, two arguments about Malthus's doctrine of population from Hazlitt's Political 
Essays: With Sketches of Public Characters (1819). About this matter, while De Quincey insists on coincidental overlapping with Hazlitt, he concludes a lengthy response by saying:

My answer to Mr. Hazlitt therefore is-that in substance I think his claim valid; and though it is most true that I was not aware of any claim prior to my own, I now formally forego any claim on my own part to the credit of whatsoever kind which shall ever arise from the two objections to Mr. Malthus's logic in his Essay on Population. (De Quincey 1823, n.p.)

It is significant-and also somewhat ironic-that De Quincey, having had to respond to accusations of plagiarizing Hazlitt in 1823, should highlight Hazlitt's dependence on echoing others more than a decade later (De Quincey 1838). However, of more pertinence to this paper is not the fact that there are personal motivations behind the critique of Hazlitt's writing style, but the fact that a text relying heavily on quotation makes it subject to criticism, something which exposes specific conceptions of authorship and ownership of language.

\section{Misquoting Shakespeare}

17 As seen above, De Quincey describes Hazlitt's reliance on echoing others as dishonest. However, unlike Gifford, he does not focus on the inaccuracy of the quotes but simply on Hazlitt's reliance on them. The dishonesty, for De Quincey, lies in the disconnection between style and man rather than in the misrepresentation of the words of others. However, Hazlitt's work is riddled with many misquotations or adaptations of sources that are very often not explicitly cited in the text and, in this context, it is inaccurate to describe Hazlitt's style simply as a mosaic of juxtaposed quotations. Indeed, while Hazlitt cites others, especially Shakespeare, assiduously, he often modifies his materials into something new. Thus, there are at least two sides to Hazlitt's style of echoing that should be considered: his juxtaposition of the words of others in his essays and his transformation of these words in his texts. The two modes of echoing are related but they are also fundamentally distinct in the way they construct notions of authorial voice and style.

One reason often given for Hazlitt's tendency to misquote is that he quoted from memory. If he depended on memory for quotations, as H.W. Garrod puts it, "the principle [guiding it] is, not mental accuracy, but sentiment. No man ever quoted so much", Garrod claims, "and in no writer [...] will you find the same quantity of misquotations" (Garrod 1929, 99). For some, like, P.P. Howe, there is "no point in trying to 'correct' Hazlitt's quotations" from Shakespeare. "When they are not from memory", Howe says about Hazlitt's quotes from King Lear, "they are from an unidentified edition of Shakespeare" (Howe 1930, 391).

Whether one is criticising or justifying Hazlitt's Shakespearean phrases, thinking of them as misquotations assumes that any departure from the exact wording of the source must be a mistake, at best a symptom of an expansive but imperfect memory and at worst a sign of a lack of scholarly rigour, an aspect of that carelessness in expression that De Quincey finds in Hazlitt. But it is arguably more productive to consider the misquotations as not simply mistakes, and it is even less likely that they are from some unidentified edition of Shakespeare, as Howe suggests.

One significant and somewhat revealing example may be found precisely in Hazlitt's letter in response to Gifford's accusation that he is too reliant on quoting Shakespeare. When Hazlitt writes, "I would not change that vice for your best virtue", Hazlitt is 
defiantly defending himself not only by once again citing Shakespeare-this time, As You Like It-but by misquoting the play. Hazlitt takes Orlando's "Tis a fault I will not change for your best virtue" (III.2, 277) and replaces the word "fault" with "vice". ${ }^{4}$ It is hard not to read this as an intentional alteration by Hazlitt, especially since "vice", which suggests immorality or wickedness, reinforces this intentionality more than the original "fault", which suggests failure due to some form of inadequacy or deficiency. Like Orlando in his love for Rosalind, Hazlitt will persevere in his passion for quoting Shakespeare, despite Gifford's resentment. In turn, Gifford, by being addressed in the words of Orlando, is posited as a Jacques figure, someone who as Hazlitt reminds us in Characters of Shakespear's Plays through another misquotation of As You Like It (II.5, 11-12), "can 'suck melancholy [sadness] out of a song, as a weasel sucks eggs"” (Hazlitt 1906b, 235). In Hazlitt's clever response, Gifford comes across as a cynic driven by resentment, someone who loves to be unhappy and simply content to, like a hermit, quit life to criticize from a distance. So much for a naïve or slightly forgetful Hazlitt misquoting the bard or weakly deferring to external authority. This is more likely a Hazlitt who appropriates Shakespeare's words into a somewhat pronounced personal voice that, in this particular instance, comes across as markedly sharp, ironic and belligerent. to Study" is also revealing. Here, Hazlitt discusses a specific instance in which he could not at first recall the exact words in two Shakespearean lines he wanted to quote:

I was at a loss the other day for the line in Henry V.

"Nice customs courtesy to great kings."

I could not recollect the word nice: I tried a number of others, such as old, grave, \&c.

-they would none of them do, but seemed all heavy, lumbering, or from the purpose: the word nice, on the contrary, appeared to drop into its place, and be ready to assist in paying the reverence required. Again,

"A jest's prosperity lies in the ear

of him that hears it."

I thought, in quoting from memory, of "A jest's success", “A jest's renown," \&c. I then turned to the volume, and there found the very word that, of all others, expressed the idea. Had Shakespear searched through the four quarters of the globe, he could not have lighted on another to convey so exactly what he meant-a casual, hollow, sounding success! I could multiply such examples, but that I am sure the reader will easily supply them himself; and they shew sufficiently that Shakespear was not (as he is often represented) a loose or clumsy writer. The bold and happy texture of his style, in which every word is prominent, and yet cannot be torn from its place without violence, any more than a limb from the body, is (one should think) the result either of vigilant pains-taking or of unerring, intuitive perception [...]. (Hazlitt 1928 [1826], 58-59)

Appealing to organic conceptions of the work, Hazlitt suggests that to change even a word from Shakespeare is a form of violence. When he is unsure, Hazlitt tells us, he goes back to the volume of his works to verify if his memory and intuition are correct because the original word is "not only the best" but also "the right one" (Hazlitt 1928 [1826], 59). In this passage, Hazlitt is talking about the precision of Shakespeare as a writer, but the autobiographical account of how this precision is revealed to him further problematizes the idea that Hazlitt's misquotations of Shakespeare are simply mistakes caused by his imperfect memory or careless scholarship.

This line of argument has been already well-established by several scholars who deem the practice of quoting and adapting the quotes, especially from Shakespeare, to be somewhat significant for an understanding of Hazlitt's work. Bate, for instance, conceives 
it in terms of sympathetic identification with a great precursor and as a way of bringing the archaic, though still powerful language of Shakespeare, no longer current, into fresh and allowable use (Bate 1984, 28-30). Others have written about the strategic value of quoting Shakespeare in Hazlitt's specific political and cultural context. As Rick Bowers puts it, "nothing is more familiar than Shakespeare" among Hazlitt's readers, so quoting him in personal essays was a way of tapping into popular culture to establish a common ground with them (Bowers 2009, 151). There is also a political dimension to the act of quoting a well-known precursor, and Paul Hamilton, for instance, sees this as critical to how Hazlitt intervenes in a specific historical context through participation in, and renovation of, a shared cultural universe. For Hamilton, Hazlitt's quoting of the "literary idiom" that forms part of the English "cultural mortgage" is characterized by change and innovation-what others will call misquotations-and "echo, allusion, resonance of past usage immediately make us aware of the redeployment inherent in words, the iteration from which we gain a sense of history" (Hamilton 2005, 72).

Such an understanding of quoting and misquoting as echoing that relates the essayist to the past while opening the essay to the reader in a different context is something that may be extended by arguing that this setting off in sometimes unexpected ways from a well-known and hallowed source can be construed as not only a signature characteristic of Hazlitt's style but also as one of the decisive ways in which Hazlitt, like other essayists, constructs a sense of a distinct authorial voice. Echoing, from this perspective, is not simply a fault of Hazlitt's writing or evidence of a patchwork style without real substance of thought, but an inventive vice, and a form of self-fashioning in the essay.

\section{Quoting and misquoting as inventive echoing}

If we consider the science of sound waves, we will find that by definition an echo needs distance of not only space in which the sound wave may travel but also time in order for it, upon its return, to be perceived by the listener as a similar but different sound, hence an echo. In this respect, echoes are different from reverberations of a sound wave, which arrive to the listener so quickly after the original sound that the mind perceives them as a prolongation of the same sound. Unlike a reverberation, an echo is perceived as a distinct sound, a recurrence-later in time-of an original.

Distance and distinction, then, are constitutive of echoing. They are inherent to it. Secondly, echoes are heard after the sound waves bounce off walls with properties that make them highly reflective and less absorbent of sound. For them to be echoed in the first place, sounds need a specific echoing space and echoing walls. There can be no echo without something external to the original sound wave that returns the sound wave to what the listener perceives as a similar but distinct sound. In this respect, then, the space and walls that make echoes possible are not simply passive conduits for sound but also co-productive of the echo.

By way of analogy, to think of Hazlitt's echoing of Shakespeare within the parameters set by the science of sound would be to think of the productive and inventive role of echoing, its not being only deferential, secondary or supplementary to an origin from which it "borrows" or which it simply stitches into a mosaic of fragments.

Alternatively, one could think in terms of how Hazlitt's echoing both uses and mentions Shakespeare. When Hazlitt quotes, he rarely explicitly cites. But he almost always marks 
the phrases with quotation marks or italics that indicate that the origins of the words lie elsewhere. This is the case even when the phrase rendered by Hazlitt is so far from the original version that it takes inventiveness and a sound knowledge of the source to discern what Hazlitt is actually echoing, as when, in "On Personal Character", Hazlitt writes, "Instinct, Hal, instinct!" (Hazlitt 1928 [1826], 233) a phrase in quotation marks that does not appear in Shakespeare but that evokes in some ways a speech by Falstaff in Henry IV Part 1:

Why, thou knowest I am as valiant as Hercules: but

beware instinct; the lion will not touch the true

prince. Instinct is a great matter; I was now a coward

on instinct. (Henry IV, Part 1, II.5, 271-276)

While he does not often cite Shakespeare by name in his familiar essays, Hazlitt clearly wants to appeal to what Marjorie Garber calls the Shakespeare "effect" (Garber 2008), the cultural desire attached to mentioning or quoting the god of his and many others' idolatry. There is a sense in which, as Bromwich argues, this kind of echoing belongs to a specific quality of sublimity, what Longinus defines as the sublime that arises from "the echo of a great soul" (Longinus 1907, ix.2).

But Hazlitt does not simply mention the words he echoes when he quotes Shakespeare. He also appropriates the words and uses them, molding them into something new, occasionally into an almost unrecognizable form. Indeed, even if the Shakespearean phrases were to be taken from the original texts verbatim and duly cited, the change in context would already make of the echoes something necessarily different from the original, but Hazlitt changes the quotations so frequently, and he uses them in contexts so different that the veering is not primarily to be thought of as a blemish or "fault" to be condemned or justified but as an inventive stylistic characteristic of his work that helps to establish even more clearly a sense of Hazlitt's individual voice as an essayist. In this respect, it is significant that in condemning Hazlitt for dishonesty and for failing to impress his individuality onto his writing, De Quincey does not refer to the fact that Hazlitt's quotations often alter the original, sometimes significantly.

Echoing for self-fashioning through style is a stylistic practice that Hazlitt himself finds in Lord Byron who, Hazlitt tells us, "takes the thoughts of others (whether contemporaries or not) out of their mouths, and is content to make them his own, to set his stamp upon them". In the case of Byron, the modifications give the lines "a more meretricious gloss, a higher relief, a greater loftiness of tone, and a characteristic inveteracy of purpose" (Hazlitt 1825, 162) thus conveying Byron's own daring and decisive personality, characterized, Hazlitt tells us, by "self-will, passion, the love of singularity, [and] a disdain of himself and of others" (Hazlitt 1825, 163).

Disdain is a feeling that Hazlitt feels and expresses often in his writing, as in "On the Pleasure of Hating", but disdain is surely not what drives Hazlitt to mention, modify, use and misuse Shakespeare in his own essays. When he extols the precision of the word "nice" in the line from Henry V or "prosperity" in Love's Labour's Lost (see above), like Echo's echoing of Narcissus in Derrida's reading of the myth, Hazlitt, "signs her [his] own love. In repeating she [he] responds to him" (Derrida 2004). From Derrida, we can also take his claim in a well-known interview that "everything is in Shakespeare" so that when one writes one is always posited in a relation of "admiration and gratitude" or of secondarity and supplementarity to Shakespeare (Derrida 1992, 67). Hazlitt's relation to Shakespeare is also marked by this sense of secondarity, which, as we have seen, Gifford 
and De Quincey criticize. But the echo-even of him who has said "everything" or, in Derrida's important qualification, "everything and the rest, so everything or nearly" (Derrida 1992, 67)-does not return exclusively to the origin of the sound. As Bate argues, many Romantic writers quote Shakespeare also "with the expectation that the original will be recognized and the felicity of its adaptation noticed" (Bate 1992 [1986], 34). The echo is also an address to an Other, the as yet unknown reader. Derrida writes about Echo that "Echo thus lets be heard by whoever wants to hear it, by whoever might love hearing it, something other than what she seems to be saying" (Derrida 2005, xii). Echo does not simply return the voice to Narcissus in an intimate dyadic relationship but inventively creates a voice for a future other by simply repeating-at a distance-what Narcissus says. She may seem passive, but she is also actively involved in relating to a future other who receives the echo. In this sense, echo both uses and mentions Narcissus's words and, in so doing, not only expresses love for Narcissus but also forges for herself and for others a sense of herself and of her love for herself.

Consider this extract from Hazlitt's essay "On the Pleasure of Hating”, in which Hazlitt discusses, among other things which we love but soon enough start hating, our favourite books: "[T]here are passages that seem as if we might brood over them all our lives, and not exhaust the sentiments of love and admiration they excite: they become favourites, and we are fond of them to a sort of dotage" (Hazlitt 1928, 134). Passages like these, Hazlitt argues, "leave [...] a taste on the palate like nectar, and we seem in reading [them] to sit with the Gods at their golden tables". However, he warns, "if we repeat [them] often in ordinary moods, [they lose their] flavour, become [...] vapid" (Hazlitt 1928, 134). This loss, which may be brought by echoing the words in ordinary, may also happen in other ways, says Hazlitt, as when we recite our favourite quotes to a friend or "some romantic situation" (Hazlitt 1928, 135). Once these phrases are echoed in these ways, we may "afterwards", in recalling the words, "miss the accompanying circumstances, and [we] regret what we have lost, and strive in vain to bring back 'the irrevocable hour"' (Hazlitt 1928, 135).

33 In Hazlitt's reflections about our relation to our favourite lines from literature, his interest is not so much in the loss of the original when it is placed in an inadequate context, that is, the violence that comes with tearing words from their organic context, but on the affective relation that we have with the words. Alternatively stated, what is mourned by Echo is not Narcissus as such but Echo's own love for Narcissus, which is lost in being expressed. It may be better, sometimes, it seems, for Echo to absorb Narcissus's voice rather than echoing it too frequently.

34 And yet, in Hazlitt's essays, there seems to be little reticence when it comes to echoing Shakespeare, possibly because the writing space of the essay form may provide a safer space for the aura of the echoing than other contexts in the sense that the essay allows for self-fashioning through echoing. Echoing in the essay is not simply a way of deferring to or sympathizing with the illustrious precursor but also of constructing arguments that may sometimes be related to the original context of the source quotation only very remotely, if at all. Consider, for instance, how Hazlitt quotes Shakespeare in "On the Prose-Style of Poets". When writing prose, Hazlitt argues, a poet "'treads the primrose path of dalliance', or ascends 'the highest heaven of invention', or falls flat to the ground. He is nothing, if not fanciful!" (Hazlitt 1928 [1826], 10).

35 Three plays are here echoed in quick succession with none of the quotes faithfully reproducing the original. Ophelia's pointing out to Laertes that he too "the primrose path 
of dalliance treads" (Shakespeare, Hamlet, I.3, 50) has the word order changed to fit the syntax while the meaning of the phrase is also significantly shifted since the connotations of sinfulness are transposed from Laertes's possibly promiscuous sexual behavior to the writing style of poets. The phrase "brightest heaven of invention", which appears in the Prologue to Henry V (Henry V, Prologue, 2) extolling the world-making powers of the Shakespearean stage, is changed by Hazlitt to "highest heaven of invention" (my italics), which perhaps is a more appropriate way of conveying his distrust of poetic style in prose. Shakespeare's "brightest", in its context, has positive connotations, while Hazlitt's "highest" suggests a loftiness (of style) that may always turn to falling. In the third echo of Shakespeare, Iago's markedly ironic "I am nothing, if not critical" (Shakespeare, Othello , I.2, 122) is turned to the italicized phrase "He is nothing, if not fanciful!" which retains the irony, echoes the syntax, but changes the words and context significantly. This particular quotation from Othello is significant for Hazlitt, who uses it a handful of times in his published work. In "A View from the English Stage", for example, Hazlitt uses the full quote to comment on Edmund Kean's performance as Iago (Hazlitt 1906a, 63). He uses it again in "The Periodical Press", in which Hazlitt reviews the periodical press of the time and argues that the fact that his time "is a critical age" stems from the fact that "so many works of genius have appeared, that they have left us [contemporaries of Hazlitt] little or nothing to do, but to think and talk about them" (Howe, vol. 16, 212). "Be it so", Hazlitt insists, for "[w]e are nothing, if not critical", thus echoing and slightly adapting Iago's words from Shakespeare to describe his own role and that of other periodical essayists of the time (Howe, vol. 16, 213). In such contexts, in which the same quotation is being used in different ways, it becomes difficult to argue that Hazlitt's misquotations of Shakespeare are simply due to his forgetfulness. On the contrary, they are clear evidence of Hazlitt's internalization, appropriation and modification of the bard's words as a form of self-fashioning.

Other such examples may be found in "On Personal Character", in which Hazlitt argues that "No one ever changes his character" from birth onwards (Hazlitt 1826, 230). There is no space or reason for us to explore whether such a strictly deterministic vision of personal character is in any way Shakespearean, but what is striking for our purposes is the repeated return to Shakespeare for phrases about the topic of personal character which Hazlitt incorporates into his argument. We read: 'It is not in our stars,' in planetary influence, but neither is it owing 'to ourselves, that we are thus or thus"' (Hazlitt 1928 [1826], 230). Hazlitt takes Cassius's words to Brutus in Julius Caesar, that "the fault [...] is not in our stars", with which Cassius argues for a belief in individual will and hence action against Caesar, and uses them to express a fundamentally different position from Cassius's: the idea that we are not in control of who we are because character is biologically inherited (Shakespeare, Julius Caesar, I.2, 141). In the second part of the sentence, Hazlitt refutes Iago's assertion that "'Tis in ourselves that we are thus or thus", so that Iago's words are quoted not to be endorsed but because they formulate a position that Hazlitt wants to negate (Shakespeare, Othello, I.3, 319). Further down, Hazlitt again echoes Shakespeare, this time turning Lady Macbeth's instructions to her husband "to beguile the time, look like the time" (Shakespeare, Macbeth, I.5, 62-63) into a description of what sometimes happens: "The designing knave", Hazlitt warns us, "may sometimes wear a vizor, or, 'to beguile the time, look like the time"' (Hazlitt 1928 [1826], 231). both mentioned and used. They are mentioned by being put in between quotation marks 
or in italics, thus gesturing at their origin elsewhere. But in being echoed, they are also decisively altered, functioning as inventive modulations for Hazlitt's thoughts about writing style. Hazlitt appropriates the basic structure of Shakespeare's syntax or imagery in a way that still allows the well-read reader to identify the original but he then actively repurposes the words and their significance, sending them to his readers sometimes in their original form and sometimes significantly refashioned.

Echoing, then, is not only a way for Echo to express love and deference. In the case of Hazlitt, echoing is also a strategic appeal, through mentioning, to the cultural value of Shakespeare, and a fashioning of one's own essayistic self through appealing to and veering from the origin. Echo signs, in her own name, when she countersigns Narcissus; Hazlitt signs in his own name when he quotes Shakespeare, and this is a defining characteristic not only of Hazlitt's relation to Shakespeare but of the essay, more widely, as a modern genre going back to Montaigne, which, as Lopate argues "sprang from quotation" (Lopate 2012, 131). One plunders texts because of their sacredness and the cultural legacy they belong to. But that plundering of others is also a way, for the essayist, to open a space for himself. By quoting and misquoting Shakespeare, Hazlitt does not simply give us Shakespeare's voice, but molds his own voice as an essayist through an openness to and an interiorisation or incorporation of the voice of his predecessor as well as a gesturing to the future reader, who shares a knowledge of and a love for Shakespeare. In echoing Narcissus, Echo tells us about herself. Her behaviour is not to be mistaken for simple meekness and deference. It is also a form of self-assertion.

\section{BIBLIOGRAPHY}

Barthes, Roland. “Theory of the Text”. Untying The Text. Robert Young (ed.). London: Routledge, 1981, 31-47.

Bate, Jonathan. “Hazlitt's Shakespearean Quotations”. Prose Studies 7.1 (1984): 26-37.

Bate, Jonathan. Shakespeare and the English Romantic Imagination. Oxford: Clarendon Press, 1992 (1986).

Bowers, Rick. "Hazlitt on Comedy, Shakespeare, Jonson, and Olives". Nineteenth Century Prose 36.1 (2009): 143-166.

De Quincey, Thomas. "Charles Lamb”, Leaders in Literature with a Notice of Traditional Errors Affecting Them, vol. 8: De Quincey's Works. Boston: Shepard and Gill, 1873 (1838), 108-160.

De Quincey, Thomas. "Letter in Reply to Hazlitt Concerning the Malthusian Doctrine of Population”. The London Magazine (4 November 1823). Available at https:// ebooks.adelaide.edu.au/q/quincey/thomas/uncollected-writings-of-thomas-de-quincey/ chapter6.html\#nrc6-1 (last accessed 16 November 2018).

Derrida, Jacques. “Preface: Veni”. Rogues: Two Essays on Reason. Pascale-Anne Brault and Michael Naas (trans.). Stanford, California: Stanford UP, 2005, xi-xv. 
Derrida, Jacques. "Speech is Blind: Derrida on 'Echo and Narcissus”. From the film Derrida, Kirby Dick and Amy Ziering Kofman (creators). Zeitgeist films, 2004. Accessed at http:// www.criticalcommons.org/Members/tkttran/clips/speech-is-blind-derrida-on-echo-andnarcissus (last accessed 16 November 2018).

Derrida, Jacques. “This Strange Institution Called Literature: An Interview with Jacques Derrida”. Acts of Literature. Derek Attridge (ed.). New York and London: Routledge, 1992.

Derrida, Jacques. Spurs: Nietzsche's Styles. Barbara Harlow (trans.). Chicago and London: U of Chicago P, 1979.

Garber, Marjorie. Shakespeare and Modern Culture. New York: Anchor Books, 2008.

Garrod, H.W. The Profession of Poetry and Other Lectures. Oxford: Clarendon Press, 1929.

Gass, William H. "From 'Erasmus and the Essay”. Essayists on the Essay: Montagne to Our Time. Carl H. Klaus and Ned Stuckey-French (eds). Iowa City: U of Iowa P, 2012, 106-109.

Gifford, William. “Hazlitt's Characters of Shakespeare's Plays". Quarterly Review 18 (1817-1818): 458-466.

Gifford, William. "Lectures on the English Poets. Delivered at the Surrey Institution. By William Hazlitt”, Quarterly Review 19 (1818): 424-434.

Hamilton, Paul. "Hazlitt and the 'Kings of Speech"'. Metaphysical Hazlitt: Bicentenary Essays. London/New York: Routledge, 2005, 68-80.

Hardie, Philip. Classicism and Christianity in Late Antique Latin Poetry. California: U of California P, forthcoming.

Hazlitt, William. A View of the English Stage: Or a Series of Dramatic Criticisms. W. Spencer Jackson (ed.). London: George Bull and Sons, 1906a.

Hazlitt, William. Characters of Shakespear's Plays. Vol. 65. Everyman's Library. Ernest Rhys (ed.). London: J.M. Dent \& Sons Limited/New York: E.P. Dutton \& Co., 1906 b.

Hazlitt, William. “A Letter to William Gifford, Esq. from William Hazlitt, Esq.” London: printed for John Miller, 1819.

Hazlitt, William. “Is Genius Conscious of its Powers?”. The Plain Speaker. London: J.M. Dent \& Sons Limited/New York: E.P. Dutton \& Co. Inc, 1928 [1826], 117-127.

Hazlitt, William. “On Application to Study”. The Plain Speaker. Everyman's Library. London: J.M. Dent \& Sons Limited, 1928 [1826], 55-65.

Hazlitt, William. “On Personal Character”. The Plain Speaker. Everyman's Library. London: J. M. Dent \& Sons Limited, 1928 [1826], 230-241.

Hazlitt, William. “On The Pleasure of Hating”. The Plain Speaker. Everyman's Library. London: J.M. Dent \& Sons Limited, 1928 [1826], 127-136.

Hazlitt, William. “On the Prose-Style of Poets”. The Plain Speaker. Everyman's Library. London: J.M. Dent \& Sons Limited, 1928 [1826], 5-16.

Hazlitt, William. The Fight and Other Writings. Tom Paulin and David Chandler (eds.). London: Penguin Books, 2000.

Hazlitt, William. The Spirit of the Age. London: Printed for Henry Colburn, 1825.

Howe, P.P. (ed.). The Complete Works of William Hazlitt. London and Toronto: J.M. Dent \& Sons, 1930. 
Hunt, Leigh. "Literary Notices: No. 48”. The Examiner 584 (7 March 1819): n.p. http:// www.lordbyron.org/doc.php?choose=LeHunt.1819.Hazlitt1.xml (last accessed 16 November 2018).

Kinnaird, John. William Hazlitt: Critic of Power. New York: Columbia UP, 1978.

Kristeva, Julia. "Word, Dialogue and the Novel". The Kristeva Reader. Toril Moi (ed.). New York: Columbia UP, 1986, 34-61.

Longinus. On the Sublime. W. Rhys Roberts (trans.). Cambridge: CUP, 1907.

Lopate, Philip. "What Happened to the Personal Essay?". Essayists on the Essay: Montaigne to Our Time. Carl H. Klaus and Ned Stuckey-French (eds). Iowa City: U of Iowa P, 2012, 127-136.

Montaigne, Michel de. "The Author to the Reader", Michel de Montaigne: Selected Essays. Charles Cotton (trans.), William Carew-Hazlitt (ed.). Mineola/New York: Dover Publications, Inc, 2011, v. Paulin, Tom. The Day Star of Liberty: William Hazlitt's Radical Style. London: Faber \& Faber, 1999.

Woolf, Virginia. “The Decay of Essay Writing”. Virginia Woolf: Selected Essays. Oxford: OUP, “Oxford's World's Classics", 2008, 3-5.

\section{NOTES}

1. Hazlitt responds, in particular, to Gifford's review of "Hazlitt's Characters of Shakespeare's Plays", Quarterly Review 18 (1817-18): 458-466, and of "Lectures on the English Poets. Delivered at the Surrey Institution. By William Hazlitt”, Quarterly Review 19 (1818): 424-434.

2. See Mario Aquilina, The Event of Style in Literature, Basingstoke and New York: Palgrave Macmillan, 2014, 33ff.

3. In his extract, William Hazlitt is citing William Gifford's “Hazlitt's Characters of Shakespeare's Plays", Quarterly Review 18 (1818): 458-466.

4. All my quotations from Shakespeare are from The Oxford Shakespeare: The Complete Works, second edition, edited by John Jowett, William Montgomery, Gary Taylor, and Stanley Wells. Oxford: OUP, 2005.

\section{ABSTRACTS}

The personal essay form has traditionally been shaped by two formidable forces, pulling in what may seem like diametrically opposed directions: the centrality of the self and a shared literary culture. This essay explores these contrary dynamics: the centripetal force that pulls the world towards the essayist and the centrifugal veering of the essayist towards a shared community of writing through the echoing of others. It does this by looking at William Hazlitt (1778-1830) and, more specifically, at Hazlitt's assiduous echoing of Shakespeare in his personal essays. Hazlitt does not simply echo Shakespeare repeatedly, but he often misquotes him or adapts his words, rarely citing him by name. The nature and function of these misquotations are key considerations in this essay, in which it is claimed that Hazlitt's misquotations of Shakespeare are not simply errors but a signature element of an essayistic style marked by an echoing that 
recalls the well-known original-thus appealing to the relevance of that which is already known by his readers-while veering from it, over and over again, into new directions as a form of selffashioning through style.

L'essai personnel obéit traditionnellement à deux principes fondamentaux, qui peuvent sembler difficilement conciliables: la place centrale occupée par le sujet et une culture littéraire partagée. Cet article examine cette dynamique contradictoire : la force centripète qui ramène constamment le propos à la figure de l'essayiste et la force centrifuge qui le conduit à se faire l'écho d'une communauté d'écriture partagée. Pour ce faire, il se penche sur l'œuvre de William Hazlitt (1778-1830) et, plus spécifiquement, sur les échos de Shakespeare dans les essais personnels de Hazlitt. Si les échos de Shakespeare sont nombreux dans son œuvre, il s'agit bien souvent d'échos déformés qui ne font pas directement référence à la source citée. Cet article tente de faire la lumière sur la nature et la fonction de ces échos déformés et de montrer qu'il ne s'agit pas là d'erreurs mais d'un trait spécifique du style de Hazlitt, caractérisé par un désir de convoquer le texte original, et ainsi de mettre à profit la pertinence d'une source bien connue, tout en s'en écartant, de manière répétée, pour forger son propre style dans la différence.

\section{INDEX}

Mots-clés: essai, écho, citation, écart, style

Keywords: essay, echo, quotation, misquotation, self-fashioning, style

\section{AUTHORS}

\section{MARIO AQUILINA}

Dr Mario Aquilina is a lecturer in the Department of English at the University of Malta, where he teaches rhetoric, theory, Shakespeare, the essay and electronic literature. Aquilina's first monograph, The Event of Style in Literature, published by Palgrave Macmillan in 2014, develops a theory of style as an event through readings of Blanchot, Derrida, Gadamer and Celan. Since then, his work has featured in journals like Oxford Literary Review and Cahiers Élisabéthains as well as in books like The Cambridge Companion to Posthumanism and the forthcoming Bloomsbury Handbook of Electronic Literature. Recently, he co-edited a 2016 special issue of CounterText on Electronic Literature with Ivan Callus. 